\title{
Differential Response of BEAS-2B and H-441 Cells to Methylene Blue Photoactivation
}

\author{
ROSALVA JOSEFINA RODRÍGUEZ-CÓRDOVA ${ }^{1}$, CINDY ALEJANDRA GUTIÉRREZ-VALENZUELA ${ }^{2}$, \\ PASANO BOJANG ${ }^{3}$, REYNALDO ESQUIVEL ${ }^{1}$, PEDRO HERNÁNDEZ ${ }^{1}$, \\ KENNETH S. RAMOS ${ }^{3}$, ROBERTO GUZMÁN-ZAMUDIO ${ }^{1,4}$ and ARMANDO LUCERO-ACUÑ $A^{1,2,4}$ \\ ${ }^{1}$ Nanotechnology Graduate Program, Department of Physics, University of Sonora, Hermosillo, México; \\ ${ }^{2}$ Department of Chemical and Metallurgical Engineering, University of Sonora, Hermosillo, México, \\ ${ }^{3}$ Department of Medicine, College of Medicine, University of Arizona, Tucson, AZ, U.S.A.; \\ ${ }^{4}$ Department of Chemical and Environmental Engineering, University of Arizona, Tucson, AZ, U.S.A.
}

\begin{abstract}
Background/Aim: Cancer incidence and mortalities are growing worldwide, therefore research and development of more effective and less invasive treatments, such as photodynamic therapy, are needed. Herein, we investigated the methylene blue (MB) photoactivation effects in lung epithelial cells (BEAS-2B) and lung adenocarcinoma cells (H-441). Materials and Methods: The reactive oxygen species (ROS) produced by the laser photoactivation of $M B$ in aqueous solutions and cell cultures were measured with probes, and the cell viability was evaluated with a colorimetric assay. Results: $M B$ up to $31.26 \mu M$ did not induce detectable effects in BEAS-2B cells. However, $H-441$ cells presented adverse effects below that concentration in the same range of fluencies studied. These results are in concordance with the ROS production in H-441 cells, while in BEAS-2B cells the production of ROS was less significant compared to the control. Conclusion: Photoactivation of $M B$ at concentrations below $31.26 \mu \mathrm{M}$ could be used for the selective treatment of $\mathrm{H}-441$ cells over non-cancer cells.
\end{abstract}

Research in photodynamic therapy (PDT) has been increasing as an alternative and promising treatment for cancer as well as unrelated diseases. PDT has been proved as a practical approach for the treatment of age-related macular degeneration $(1,2)$, microbial infections (3-5), atherosclerosis (6), and psoriasis (7). Additionally, research on the effectiveness of PDT in different

Correspondence to: Armando Lucero-Acuña, Department of Chemical and Metallurgical Engineering, University of Sonora, Blvd. Luis Encinas y Rosales S/N, Col. Centro, Hermosillo, Sonora, 83000, México. Tel: +52 6622592105,e-mail: armando.lucero@ unison.mx

Key Words: Photodynamic therapy, lung cancer, methylene blue, ROS production. types and locations of cancer has been reported (8-11). Methylene blue (MB) has been of great interest in PDT due to its ability to absorb light intensively within the therapeutic window, and upon radiation, it damages biomolecules by producing reactive oxygen species (ROS) (12). ROS are involved in several biological functions, but when overproduced, they can lead to cell death (13-16). ROS quantification could provide information concerning the effectiveness of PDT. Fluorescent probes, such as 2',7'-dichlorodihydrofluorescein diacetate (DCFH-DA) and 1,3-Diphenylisobenzofuran (DPBF), are used to determinate ROS in solutions and cell cultures due to their high sensitivity and facile determination (17-23). Previous studies of PDT using MB in squamous cell carcinoma have reported a decrease in tumor size and cell proliferation, and an increase in cytokine levels (11). Recently it was shown that the effect of photoactivated MB in non-malignant epithelial cell lines and different molecular subtypes of breast tumors had a higher impact on the malignant cell lines, without affecting nonmalignant cells at a significant level (9). The objective of this study was to evaluate the MB photoactivation-induced differential response in lung epithelial (BEAS-2B) and lung adenocarcinoma cells (H-441). Our results indicate a differential response of MB photoactivation between BEAS-2B and $\mathrm{H}-441$ cells.

\section{Materials and Methods}

Determination of ROS in solutions. The photoactivation of MB was evaluated in aqueous solutions to correlate the concentration of $\mathrm{MB}$ and the energy fluence with the generation of ROS. AqueousDMSO solutions of $50 \mu \mathrm{M}$ DPBF (Sigma-Aldrich, St. Louis, MO, USA) and $6.25 \mu \mathrm{M}$ or $31.26 \mu \mathrm{M}$ of MB (Química Suastes, Del Tlalpan, CMX, Mexico) were prepared. Solutions were irradiated every 2 seconds (s) with an energy fluence of $0.2 \mathrm{~J} / \mathrm{cm}^{2}$ using a red laser $(660 \mathrm{~nm}, 100 \mathrm{~mW})$. UV/VIS absorption spectra were collected using a Genesis 10S spectrophotometer (Thermo Fisher Scientific, Waltham, MA, USA). 

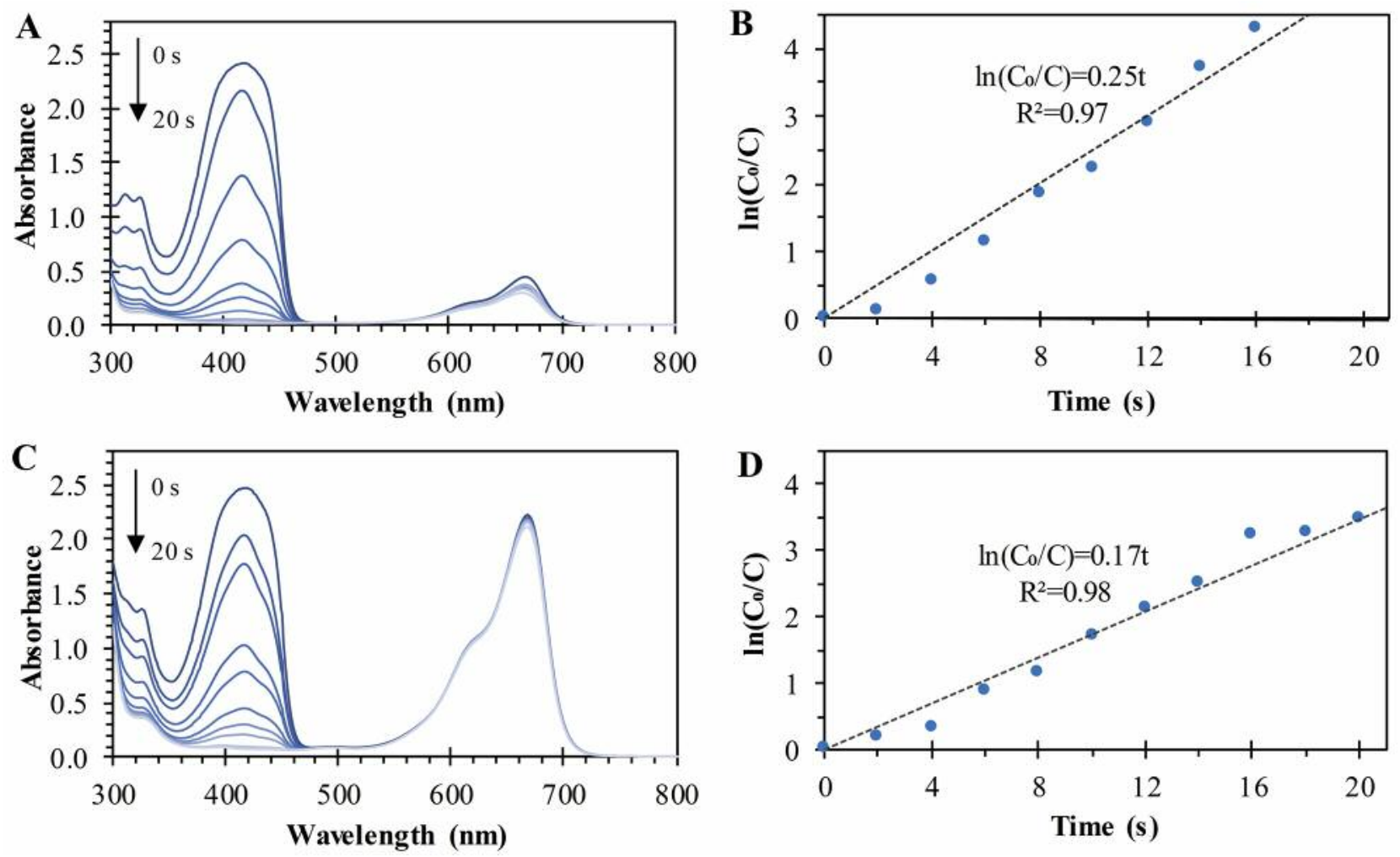

Figure 1. DPBF decay following irradiation in the presence of $6.25 \mu M$ of $M B(A)$ and $31.26 \mu M$ of $M B(C)$. Proportionality between DPBF absorbance decay and the irradiation time in the presence of $6.25 \mu M$ of $M B(B)$ and $31.26 \mu M$ of $M B(D)$.

Cell culture. BEAS-2B cells and H-441 cells were cultured in LHC-9 serum-free media and RPMI complete media (Thermo Fisher Scientific, Waltham, MA, USA), respectively, and were incubated at $37^{\circ} \mathrm{C}$ in a $5 \% \mathrm{CO}_{2}$ environment. Cells were seeded $\left(43,750\right.$ cells $\left./ \mathrm{cm}^{2}\right)$ in 96-well plates 24 hours before experimentation. Cells were treated with MB solution in LCH-9 and serum-free RPMI media, respectively for each cell line, at different concentrations $(0-156 \mu \mathrm{M})$, and were incubated for 3 hours. Then, media was removed, and cells were washed three times, twice with Dulbecco's phosphate-buffered saline (Thermo Fisher Scientific, Waltham, MA, USA) and once with media.

In vitro PDT treatment. Fresh LCH-9 and serum-free RPMI media were added to BEAS-2B and $\mathrm{H}-441$ cell cultures, respectively, for PDT treatment $(5,24,25)$. Cells were irradiated with energy fluence ranging between 0 and $36 \mathrm{~J} / \mathrm{cm}^{2}$.

Determination of intracellular ROS. Cells were cultured as described previously and were treated with HDFC-DA (Biotium) at a final concentration of $5 \mu \mathrm{M}$. Then, cells were incubated at $37^{\circ} \mathrm{C}$ for 40 minutes followed by in vitro PDT treatment as described before. Two hours following PDT treatment, fluorescence intensity was quantified by excitation at $485 \mathrm{~nm}$ and emission at $528 \mathrm{~nm}$ using a cell imaging reader (BioTek, Winooski, VT, USA).

Determination of cell survival. Following PDT treatment cells were incubated for 36 hours, and a colorimetric 3-(4, 5-dimethyle thiazol2-yl)-2, 5-diphenyl tetrazolium bromide (MTT) assay was carried to quantify cell survival (25-27).
Statistical analysis. All the experiments for the determination of intracellular ROS and cell survival produced for the applied treatments were compared between groups using paired Student's $t$-tests assuming equal variances. When the $p$-values were minor than 0.05 , the differences were considered statistically significant.

\section{Results and Discussion}

ROS production by MB photoactivation in aqueous-DMSO solutions was verified following the DPBF absorbance decay at $417 \mathrm{~nm}$, as presented in Figure $1 \mathrm{~A}$ and $\mathrm{C}$. This decay is caused by ROS produced in the form of singlet oxygen. DPBF absorbance peak was maintained constant in irradiated solutions free of MB (results not shown here), confirming that irradiation by itself does not produce ROS in the range of fluence studied. When MB was applied, a proportionality between DPBF absorbance decay and the irradiation time was observed $(12,28)$. These proportionalities are presented in Figure $1 \mathrm{~B}$ and $\mathrm{D}$ for $\mathrm{MB}$ concentrations of $6.25 \mu \mathrm{M}$ and $31.26 \mu \mathrm{M}$, respectively. These figures were plotted by considering the first-order decay of DPBF (28-31). DPBF decay constants were $0.25 \mathrm{~s}^{-1}$ and $0.17 \mathrm{~s}^{-1}$ for the respective concentrations of $\mathrm{MB}$ of $6.25 \mu \mathrm{M}$ and $31.26 \mu \mathrm{M}$. These values are proportional to the ROS generation for each 

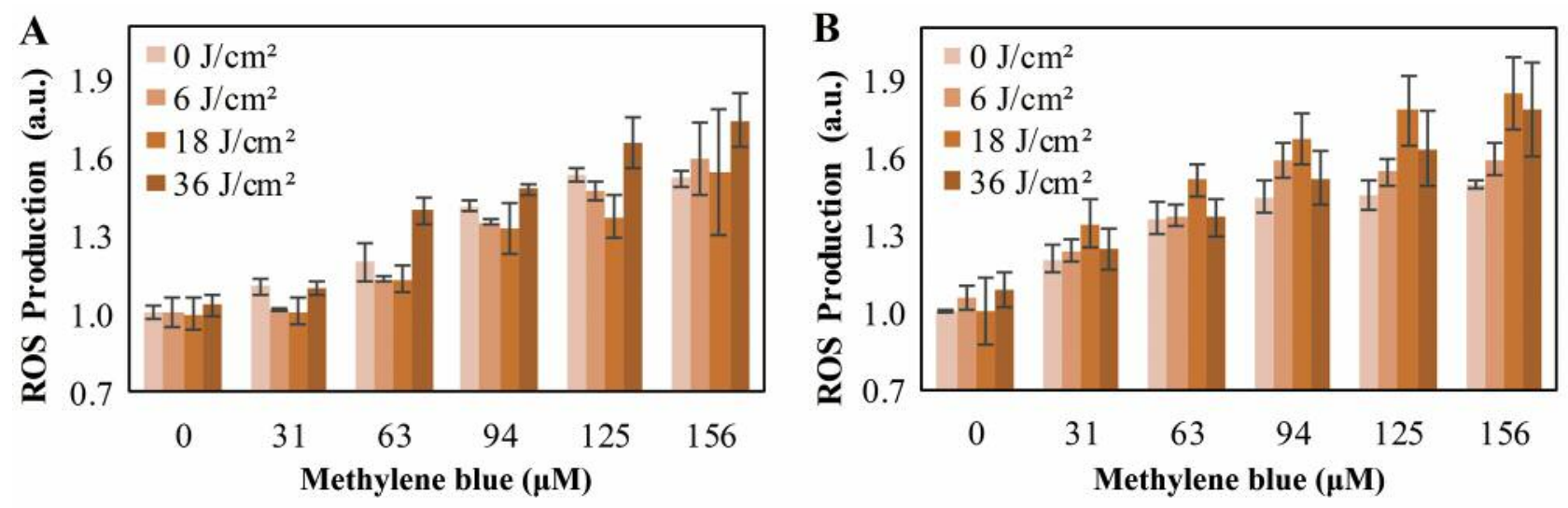

Figure 2. ROS production in (A) BEAS-2B and (B) H-441 cells after treatment with MB concentrations ranging from 0 to $156 \mu M$ in combination with energy fluence of $0 \mathrm{~J} / \mathrm{cm}^{2}, 6 \mathrm{~J} / \mathrm{cm}^{2}, 18 \mathrm{~J} / \mathrm{cm}^{2}$, and $36 \mathrm{~J} / \mathrm{cm}^{2}$. Data presented with respect to sample controls (value of 1). Data represent the mean \pm standard deviation for $n=3$. Arbitrary units $(a . u)$.
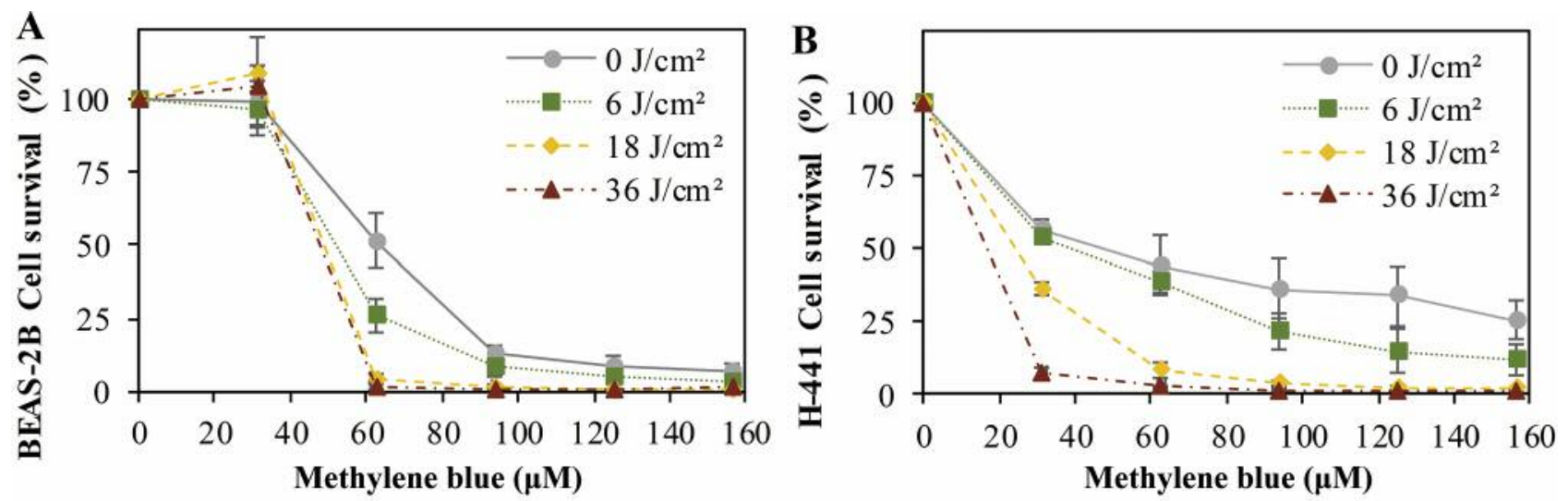

Figure 3. Cell viability of (A) BEAS-2B and (B) H-441 cells after PDT with $M B(0-156 \mu M)$ in combination with energy fluence of $0 \mathrm{~J} / \mathrm{cm}^{2}(\bullet)$, $6 \mathrm{~J} / \mathrm{cm}^{2}(\mathbf{\square}), 18 \mathrm{~J} / \mathrm{cm}^{2}(\bullet)$, and $36 \mathrm{~J} / \mathrm{cm}^{2}(\mathbf{\Delta})$. Data represent the mean \pm standard deviation for $n=3$.

experiment; it is noted that for lower concentration of $\mathrm{MB}$, more ROS were produced. This effect could be explained by the formation of dimers, which are less effective generators of ROS $(12,28)$. Also, MB absorbance peak at $665 \mathrm{~nm}$ decayed with irradiation time, as could be observed in Figure $1 \mathrm{~A}$ and $\mathrm{C}$, indicating a degree of aggregation of $\mathrm{MB}$ and confirming the presence of dimers $(12,32)$.

ROS generated in the cell cultures were measured by their reaction with DCFH-DA, producing the fluorescent molecule 2,7-dichlorofluorescein (DCF). Figure 2 shows DCF fluorescence increments for the different concentrations of $M B$ and the different levels of energy fluence evaluated. ROS were produced in BEAS-2B and H-441 cells without $\mathrm{MB}$ and irradiation. This result could be attributed to some oxidative stress caused by the cell culture process itself, facilitating the generation of reactive species (33).
Fluorescence results are presented in arbitrary units (a.u) by adjusting to the controls (without MB and irradiation). BEAS-2B and H-441 cell survival at different MB concentrations and different levels of energy fluence are presented in Figure 3A and B, respectively.

In general, an increment in the ROS production concerning the $\mathrm{MB}$ concentration was observed, as depicted in Figures $2 \mathrm{~A}$ and $2 \mathrm{~B}$, for BEAS-2B and $\mathrm{H}-441$ cells, respectively. Also, the energy fluence by itself does not contribute to the ROS production, with no significant statistical differences, as shown in Figure 2A and B. Figure $2 \mathrm{~A}$ for BEAS-2B cells shows no significant statistical differences related to the energy fluence between $31 \mu \mathrm{M}$ and $63 \mu \mathrm{M}$ of $\mathrm{MB}$, except at the set of values of $36 \mathrm{~J} / \mathrm{cm} 2$ and $63 \mu \mathrm{M}$ of MB. At this set of values, the BEAS-2B cell survival drops remarkably from $100 \%$ to $0 \%$, as observed in 
Figure 3A. The ROS values obtained in BEAS-2B at concentrations above $63 \mu \mathrm{M}$ of $\mathrm{MB}$ for all the energy fluence used displayed similar magnitudes to those obtained at the set of values at $36 \mathrm{~J} / \mathrm{cm}^{2}$ and $63 \mu \mathrm{M}$ of $\mathrm{MB}$. In consequence, the survival rates drop substantially for all the energy fluence used, as shown in Figure 3A.

Non-irradiated BEAS-2B and H-441 cells at different MB concentrations present significant statistical differences, as shown in Figures $2 \mathrm{~A}$ and $3 \mathrm{~A}$. This result indicates that $\mathrm{MB}$ itself is inducing ROS generation in both cell lines. However, the laser irradiation in BEAS-2B contributes to significant differences compared to $\mathrm{H}-441$ with regards to the ROS generation at concentrations above $31 \mu \mathrm{M}$ of $\mathrm{MB}$ and energy fluence of $36 \mathrm{~J} / \mathrm{cm}^{2}$. Besides, the laser irradiation in $\mathrm{H}-441$ cells does not contribute significantly in the ROS production at any concentration of MB. In contrast, H-441 cell survival drops significantly at concentrations of $31 \mu \mathrm{M}$ of $\mathrm{MB}$, and above, when the laser irradiation increases, as observed in Figure 3A. This outcome could be explained by the formation of dimers, as observed in the experiments for the determination of ROS in solutions. MB dimers are less effective generators of ROS (28).

The half maximal inhibitory concentration $\left(\mathrm{IC}_{50}\right)$ of BEAS2B cells with $\mathrm{MB}$ and energy fluence of $0 \mathrm{~J} / \mathrm{cm}^{2}, 6 \mathrm{~J} / \mathrm{cm}^{2}, 18$ $\mathrm{J} / \mathrm{cm}^{2}$, and $36 \mathrm{~J} / \mathrm{cm}^{2}$, resulted in values of $63.5 \mu \mathrm{M}, 52 \mu \mathrm{M}, 49$ $\mu \mathrm{M}$, and $48 \mu \mathrm{M}$ of $\mathrm{MB}$, respectively (Figure $3 \mathrm{~A}$ ). The results for H-441 cell survival show decrements for all the concentrations of $\mathrm{MB}$ analyzed, including the samples not irradiated. $\mathrm{H}-441$ cells treated with $\mathrm{MB}$ and energy fluence of $0 \mathrm{~J} / \mathrm{cm}^{2}, 6 \mathrm{~J} / \mathrm{cm}^{2}, 18 \mathrm{~J} / \mathrm{cm}^{2}$, and $36 \mathrm{~J} / \mathrm{cm}^{2}$, resulted in values of $\mathrm{IC}_{50}$ of $47 \mu \mathrm{M}, 39 \mu \mathrm{M}, 24 \mu \mathrm{M}$, and $17 \mu \mathrm{M}$ of MB, respectively (Figure 3B). This means that lung adenocarcinoma $\mathrm{H}-441$ cells are more sensitive to PDT with MB compared to lung epithelial BEAS-2B cells. This result is consistent with other works reporting that $\mathrm{MB}$ was more toxic in erythroleukemic cells compared to normal peripheral blood mononuclear cells (34). Studies of PDT using MB in lung adenocarcinoma A549 cells have shown an enhancement of apoptosis associated with downregulation of anti-apoptotic proteins, reducing the mitochondrial membrane potential and increasing phosphorylation of the mitogen-activated protein kinase and the generation of ROS (8). Also, other studies of PDT with MB in B16F1 melanoma cells shows mitochondria-related apoptosis through a series of steps beginning with the photochemical generation of ROS that activate the caspase-9/ caspase-3 apoptosis pathway (35). Similarly, PDT with MB in HeLa tumor cells triggered apoptotic cell dead by a mitochondria-dependent apoptotic pathway (36). Other works report the enhancement of ROS production and cell death $(\mathrm{CHO})$ by using a combination of light and ultrasound activation of MB (37). In addition, derivatives of $\mathrm{MB}$ have been reported in the literature, where longer alkyl chains substituted the methyl groups of $\mathrm{MB}$, resulting in more phototoxic effects than MB in RIF-1 murine fibrosarcoma cells. This effect was explained by the accumulation of the derivatives in the mitochondria (25).

This work presents the differential response of BEAS-2B and $\mathrm{H}-441$ cells to $\mathrm{MB}$ photoactivation. The increments of ROS produced by $\mathrm{MB}$ photoactivation are directly related to BEAS-2B and H-441 cell survival. Results suggest that oxidative stress caused by ROS could be adjusted by modifying $\mathrm{MB}$ concentrations or different levels of energy fluence. Concentrations of MB above $31.26 \mu \mathrm{M}$ are required to decrease BEAS-2B cell survival, while $\mathrm{H}-441$ cell survival was similarly affected at a lower MB concentration. These results are in concordance with ROS production in BEAS-2B and H-441 cells, where larger production was obtained in H-441 cells. Therefore, selective cell damage could be achieved by using MB in PDT of lung cancer.

\section{Conflicts of Interest}

The Authors declare no conflicts of interest.

\section{Authors' Contributions}

RJRC and CAGV performed all experiments. PB, RE, PH, KSR, and RGZ contributed with reagents/materials/analysis tools and discussion for all experiments. ALA conceived and designed the experiments and contributed to the writing of the manuscript.

\section{Acknowledgements}

Financial assistance was provided through the Secretariat of Public Education of Mexico (SEP) with the project UNISON-PTC-222 DSA/103.5/15/7356. RJR-C and $\mathrm{PH}$ would like to thank CONACYT for the PhD scholarship.

\section{References}

1 Brodowska K, Al-Moujahed A, Marmalidou A, Meyer zu Horste M, Cichy J, Miller JW, Gragoudas E and Vavvas DG: The clinically used photosensitizer Verteporfin (VP) inhibits YAPTEAD and human retinoblastoma cell growth in vitro without light activation. Exp Eye Res 124: 67-73, 2014. PMID: 24837142. DOI: 10.1016/j.exer.2014.04.011

2 Ghazi NG, Jabbour NM, De La Cruz ZC and Green WR: Clinicopathologic studies of age-related macular degeneration with classic subfoveal choroidal neovascularization treated with photodynamic therapy. Retina 21: 478-486, 2001. PMID: 11642377. DOI: $10.1097 / 00006982-200110000-00010$

3 Braun A, Dehn C, Krause F and Jepsen S: Short-term clinical effects of adjunctive antimicrobial photodynamic therapy in periodontal treatment: A randomized clinical trial. J Clin Periodontol 35: 877-884, 2008. PMID: 18713259. DOI: 10.1111/j.1600-051X.2008.01303.x

4 Dai T, Fuchs BB, Coleman JJ, Prates RA, Astrakas C, St. Denis TG, Ribeiro MS, Mylonakis E, Hamblin MR and Tegos GP: Concepts and principles of photodynamic therapy as an alternative antifungal discovery platform. Front Microbiol 3: 116, 2012. PMID: 22514547. DOI: 10.3389/fmicb.2012.00120 
5 Teichert MC, Jones JW, Usacheva MN and Biel MA: Treatment of oral candidiasis with methylene blue-mediated photodynamic therapy in an immunodeficient murine model. Oral Surgery, Oral Med Oral Pathol Oral Radiol 93: 155-160, 2002. PMID: 11862203. DOI: $10.1067 /$ moe.2002.120051

6 Waksman R, McEwan PE, Moore TI, Pakala R, Kolodgie FD, Hellinga DG, Seabron RC, Rychnovsky SJ, Vasek J, Scott RW and Virmani R: PhotoPoint photodynamic therapy promotes stabilization of atherosclerotic plaques and inhibits plaque progression. J Am Coll Cardiol 52: 1024-1032, 2008. PMID: 18786486. DOI: $10.1016 / j$.jacc.2008.06.023

7 Salah M, Samy N and Fadel M: Methylene blue mediated photodynamic therapy for resistant plaque psoriasis. J Drugs Dermatol 8: 42-49, 2009. PMID: 19180895.

8 Lim EJJ, Oak C-H, Heo JJ and Kim Y-H: Methylene bluemediated photodynamic therapy enhances apoptosis in lung cancer cells. Oncol Rep 30: 856-862, 2013. PMID: 23708127. DOI: $10.3892 / o r .2013 .2494$

9 dos Santos AF, Terra LF, Wailemann RAM, Oliveira TC, Gomes VDM, Mineiro MF, Meotti FC, Bruni-cardoso A, Baptista MS and Labriola L: Methylene blue photodynamic therapy induces selective and massive cell death in human breast cancer cells BMC Cancer 17: 1-15, 2017. PMID: 28298203. DOI: 10.1186/ s12885-017-3179-7

10 Banerjee SM, Macrobert AJ, Mosse CA, Periera B, Bown SG and Keshtgar MRS: Photodynamic therapy: Inception to application in breast cancer. The Breast 31: 105-113, 2017. PMID: 27833041. DOI: 10.1016/j.breast.2016.09.016

11 Silva AP, Lima-Neves C, dos Anjos-Silva A, Lima-Portela CT, Stecca-Iunes R, Cogliati B, Severino D, da Silva-Baptista M, Zaidan-Dagli ML, Hernandez-Blazquez FJ, Dagli Z, HernandezBlazquez FJ and Machado Cunha da Silva JR: Photodiagnosis and photodynamic therapy effects of methylene blue-mediated photodynamic therapy on a mouse model of squamous cell carcinoma and normal skin. Photodiagnosis Photodyn Ther 23: 154164, 2018. PMID: 29908976. DOI: 10.1016/j.pdpdt. 2018.06.012

12 Tardivo JPJP, Del Giglio A, De Oliveira CS, Gabrielli DS, Junqueira HC, Tada DB, Severino D, de Fátima Turchiello R, Baptista MS, De Fattima Turchiello R, Baptista MS, Turchiello RDF, Baptista MS, de Fátima Turchiello R, Baptista MS, De Fattima Turchiello R and Baptista MS: Methylene blue in photodynamic therapy: From basic mechanisms to clinical applications. Photodiagnosis Photodyn Ther 2: 175-191, 2005. PMID: 25048768. DOI: 10.1016/S1572-1000(05)00097-9

13 Aureliano DP, Angelo J, Lindoso L, Regina S and Soares DC: Photodiagnosis and Photodynamic Therapy Cell death mechanisms in Leishmania amazonensis triggered by methylene blue-mediated antiparasitic photodynamic therapy. Photodiagnosis Photodyn Ther 23: 1-8, 2018. PMID: 29751117. DOI: 10.1016/ j.pdpdt.2018.05.005

14 Sibata CH, Colussi VC, Oleinick NL, Kinsella TJ, Lam M, Oleinick NL and Nieminen A-L: Photodynamic therapy: A new concept in medical treatment. Brazilian J Med Biol Res 33: 869880, 2000. PMID: 11023333. DOI: 10.1074/jbc.M107678200

15 Cho K, Wang X, Nie S, Chen ZG and Shin DM: Therapeutic nanoparticles for drug delivery in cancer. Clin Cancer Res 14: 1310-6, 2008. PMID: 18316549. DOI: 10.1158/1078-0432.CCR07-1441

16 Kwiatkowsk S, Knap B, Przystupski D, Saczko J, Ewa K, Knapczop K, Kotli J, Michel O, Kotowski K and Kulbacka J:
Photodynamic therapy - mechanisms, photosensitizers and combinations. Biomed Pharmacother 106: 1098-1107, 2018. PMID: 30119176. DOI: 10.1016/j.biopha.2018.07.049

17 Gomes A, Fernandes E and Lima JLFC: Fluorescence probes used for detection of reactive oxygen species. J Biochem Biophys Methods 65: 45-80, 2005. PMID: 16297980. DOI: 10.1016/j.jbbm.2005.10.003

18 Tanaka K, Miura T, Umezawa N, Urano Y, Kikuchi K, Higuchi $\mathrm{T}$ and Nagano $\mathrm{T}$ : Rational design of fluorescein-based fluorescence probes. Mechanism-based design of a maximum fluorescence probe for singlet oxygen. J Am Chem Soc 123: 2530-2536, 2001. PMID: 11456921. DOI: 10.1021/ja0035708

19 Kalyanaramana B, Darley-Usmarb V, Davies KJ, Dennerye PA, Formanc HJ, Grisham MB, Mann GE, Moorei K, Roberts LJ 2nd and Ischiropoulose $\mathrm{H}$ : Measuring reactive oxygen and nitrogen species with fluorescent probes: challenges and limitations. Free Radic Biol Med 45: 1-6, 2013. PMID: 22027063. DOI: 10.1016/ j.freeradbiomed.2011.09.030.Measuring

20 Aranda A, Sequedo L, Tolosa L, Quintas G, Burello E, Castell JV and Gombau L: Dichloro-dihydro-fluorescein diacetate (DCFH-DA) assay: A quantitative method for oxidative stress assessment of nanoparticle-treated cells. Toxicol Vitr 27: 954963, 2013. PMID: 23357416. DOI: 10.1016/j.tiv.2013.01.016

21 Gutiérrez-Valenzuela CA, Rodríguez-Córdova R, HernándezGiottonini Y, Guerrero-Germán P and Lucero-Acuña A: methylene blue loaded PLGA nanoparticles: combined emulsion, drug release analysis and photodynamic activity. Microsc Microanal 23: 12121213, 2017. DOI: $10.1017 /$ S143 1927617006729

22 Rastogi RP, Singh SP, Häder D and Sinha RP: Detection of reactive oxygen species (ROS) by the oxidant-sensing probe 2', 7'-dichlorodihydrofluorescein diacetate in the cyanobacterium Anabaena variabilis PCC 7937. Biochem Biophys Res Commun 397: 603-607, 2010. PMID: 20570649. DOI: 10.1016/ j.bbrc. 2010.06.006

23 Oparka M, Walczak J, Malinska D, van Oppen LMPE, Szczepanowska J, Koopman WJH and Wieckowski MR: Quantifying ROS levels using CM-H2DCFDA and HyPer. Methods 109: 3-11, 2016. PMID: 27302663. DOI: 10.1016/ j.ymeth.2016.06.008

24 Lam M, Oleinick NL and Nieminen A-L: Photodynamic therapyinduced apoptosis in epidermoid carcinoma cells. J Biol Chem 276: 47379-47386, 2001. PMID: 11579101. DOI: 10.1074/ jbc.M107678200

25 Mellish KJ, Cox RD, Vernon DI, Griffiths J and Brown SB: In vitro photodynamic activity of a series of methylene blue analogues. Photochem Photobiol 75: 392, 2002. PMID: 12003129. DOI: 10.1562/0031-8655(2002)0750392IVPA OA2.0.CO2

26 Klepac-Ceraj V, Patel N, Song X, Holewa C, Patel C, Kent R, Amiji MM and Soukos NS: Photodynamic effects of methylene blue-loaded polymeric nanoparticles on dental plaque bacteria. Lasers Surg Med 43: 600-606, 2011. PMID: 22057487. DOI: $10.1002 / 1 \mathrm{sm} .21069$

27 Van Meerloo J, Kaspers GJL and Cloos J: Cell Sensitivity Assays: The MTT Assay. In: Methods in Molecular Biology. pp. 237-245, 2011. PMID: 21516412. DOI: 10.1007/978-1-61779080-5

28 Craig RA, McCoy CP, De Baróid ÁT, Andrews GP, Gorman SP and Jones DS: Quantification of singlet oxygen generation from photodynamic hydrogels. React Funct Polym 87: 1-6, 2015. DOI: $10.1016 /$ j.reactfunctpolym.2014.11.009. 
29 Zhang XF and Li X: The photostability and fluorescence properties of diphenylisobenzofuran. J Lumin 131: 2263-2266, 2011. DOI: 10.1016/j.jlumin.2011.05.048

30 Bonacin J, Engelmann F, Severino D, Toma H and Baptista M: Singlet oxygen quantum yields $(\phi)$ in water using beetroot extract and an array of LEDs. J Braz Chem Soc 20: 31-36, 2009. DOI: $10.1590 / \mathrm{S} 0103-50532009000100006$

31 Deprá de Souza T, Ziembowicz FI, Muller DF, Lauermann SC, Kloster CL, Vianna Santos RC, Soares Lopes LQ, Ferreira Ourique A, MacHado $G$ and Villetti MA: Evaluation of photodynamic activity, photostability and in vitro drug release of zinc phthalocyanine-loaded nanocapsules. Eur J Pharm Sci 83: 88-98, 2016. PMID: 26678154. DOI: 10.1016/j.ejps.2015. 12.006

32 Blázquez-Castro A, Stockert JC, Sanz-Rodríguez F, Zamarrón A and Juarranz A: Differential photodynamic response of cultured cells to methylene blue and toluidine blue: role of dark redox processes. Photochem Photobiol Sci 8: 371-376, 2009. PMID: 19255678. DOI: 10.1039/b818585a

33 Halliwell B and Whiteman M: Measuring reactive species and oxidative damage in vivo and in cell culture: how should you do it and what do the results mean? Br J Pharmacol 142: 231-255, 2004. PMID: 15155533. DOI: 10.1038/sj.bjp.0705776

34 Kirszberg C, Rumjanek VM and Capella MAM: Methylene blue is more toxic to erythroleukemic cells than to normal peripheral blood mononuclear cells: A possible use in chemotherapy. Cancer Chemother Pharmacol 56: 659-665, 2005. PMID: 16052340. DOI: 10.1007/s00280-005-1014-3
35 Chen Y, Zheng W, Li Y, Zhong J, Ji J and Shen P: Apoptosis induced by methylene-blue-mediated photodynamic therapy in melanomas and the involvement of mitochondrial dysfunction revealed by proteomics. Cancer Sci 99: 2019-2027, 2008. PMID: 19016762. DOI: 10.1111/j.1349-7006.2008.00910.x

$36 \mathrm{Lu} \mathrm{Y,} \mathrm{Jiao} \mathrm{R,} \mathrm{Chen} \mathrm{X,} \mathrm{Zhong} \mathrm{J,} \mathrm{Ji} \mathrm{A} \mathrm{and} \mathrm{Shen} \mathrm{P:} \mathrm{Methylene}$ blue-mediated photodynamic therapy induces mitochondriadependent apoptosis in HeLa cell. J Cell Biochem 105: 14511460, 2008. PMID: 18980251. DOI: 10.1002/jcb.21965

37 McCaughan B, Rouanet C, Fowley C, Nomikou N, McHale AP, McCarron PA and Callan JF: Enhanced ROS production and cell death through combined photo- and sono-activation of conventional photosensitising drugs. Bioorganic Med Chem Lett 21: 5750-5752, 2011. PMID: 21875807. DOI: 10.1016/j.bmcl. 2011.08.015 